\title{
MENINGKATKAN PRESTASI BELAJAR MATEMATIKA SISWA KELAS XI IPA 7 SEMESTER 3 YANG DIUPAYAKAN DENGAN PENERAPAN MODEL PEMBELAJARAN CONTEXTUAL TEACHING AND LEARNING (CTL) SMA NEGERI 1 DENPASARTAHUN PELAJARAN 2016/2017
}

\author{
A.A Gede Bagus Supartapa \\ SMA Negeri 1 Denpasar \\ Email: supartapa.math@gmail.com
}

\begin{abstract}
ABSTRAK
Penelitian ini dilakukan di Kelas XI IPA 7 semester 3 tahun pelajaran 2016/2017, berjumlah 34 orang, 11 orang laki-laki, dan 23 orang perempuan. Pembelajaran matematika dengan metode ceramah hasilnya jauh dari KKM (80), kemudian dicoba dengan metode diskusi hasilnya juga belum tercapai secara keseluruhan. Tujuan dari penelitian ini adalah untuk menganalisisapakah model pembelajaran CTL dapat meningkatkan prestasi belajar matematika siswa. Datanya dikumpulkan dengan cara pemberian tes. Analisis datanya adalah analisis deskriptif. Data awal rata-rata 78,38 dan ketuntasan belajarnya $61,76 \%$. Data ini jauh di bawah KKM (80) mengingat indikator keberhasilan belajar siklus I adalah 80 ,ketuntasan belajar $80 \%$. Indikator keberhasilan siklus II juga sesuai KKM yaitu 80 , ketuntasan belajar $85 \%$ Siklus I sudah ada peningkatkan dengan rata-rata 79,18 dan ketuntasan belajar 73,53\%. Siklus II rata-rata 84,00 persentase ketuntasan belajarnya 97,06 \% . Kesimpulannya adalah model pembelajaran Contextual Teaching And Learning (CTL) dapat meningkatkan prestasi belajar.
\end{abstract}

Kata Kunci: Contextual Teaching And Learning (CTL), Hasil Belajar

\begin{abstract}
This classroom action research conducted in Class XI Science 7 3rd semester of academic year 2016/2017, which amounted to 34 people, consisting of 11 men and 23 women. This study aims to improve student learning outcomes. Learning mathematics with the lecture method the results are far from KKM (80), and then tested by the method of discussion with friends bench results have not yet been achieved overall. The purposes of this researsh were to analyze how learning model Contextual Teaching and Learning (CTL) can improve students' learning achievement. Research data was collected by means of the provision of learning achievement test. In analyzing the data obtained is used descriptive analysis model. The data generated from this study consists of the data: the beginning, the first cycle and cycle II. From the preliminary data obtained an average value of 78.38 and reached $61.76 \%$ mastery learning. This data is far below expectations considering learning success indicators in the first cycle is 80 to $80 \%$ mastery learning. While indicators of success on the second cycle also according KKM is 80 , with $85 \%$ or completeness learn more. In the first cycle there is an average increase class achieve mastery learning 79.18 and reached $73.53 \%$. In the second cycle class average acquisition has reached 84.0 and the percentage of mastery learning has reached 97.06\%. Data on the second cycle has been no increase in line with expectations due to the nature of the use of constructivist learning model. The conclusion from this research is learning model Contextual Teaching and Learning (CTL) can improve learning achievement.
\end{abstract}

Keywords: Model Learning Contextual Teaching and Learning (CTL), academic achievement

\section{PENDAHULUAN}

Sekolah merupakan salah satu tempat berlangsungnya proses belajar mengajar. Adapun komponen-komponen proses belajar mengajar adalah sekolah sebagai tempat terjadinya proses, guru tugas utamanya mengajar dan siswa tugas 
utamanya belajar. Keterkaitan antara komponen-komponen itu disebut pembelajaran. Beberapa karakteristik pembelajaran yaitu pembelajaran siswa,berlangsung dimana saja,dan berorientasi pada pencapaian tujuan,(Wina Sanjaya,2006).Pada saat ini aktifitas belajar siswa sangat rendah antara lain pada pelajaran Matematika. Hal ini dikarenakan kurangnya keterampilan guru dalam mengelola metode atau model pembelajaran, akibatnya fokus pembelajaran berada pada guru dan kurangnya partisifasi siswa secara aktif. Pembelajaran Matematika umumnya didominasi oleh pengenalan rumus-rumus serta konsep-konsep secara verbal, tanpa ada perhatian yang cukup terhadap pemahaman siswa. Disamping itu proses belajar mengajar hampir selalu berlangsung guru menjadi pusat dari seluruh kegiatan di kelas. Pembelajaran matematika sering diinterpretasikan sebagai aktivitas utama yang dilakukan guru, yaitu guru mengenalkan materi, mungkin mengajukan satu atau dua pertanyaan, dan meminta siswa yang pasif untuk lebih aktif dengan memulai melengkapi latihan dari buku teks, pelajaran diakhiri dengan pengorganisasian yang baik dan pembelajaran selanjutnya dilakukan dengan sekenario yang serupa. Kondisi di atas tampak lebih parah pada pembelajaran Statistik dan Peluang. Sebagian siswa tidak mengetahui mengapa dan untuk apa mereka belajar konsepkonsep Statistik dan Peluang, karena semua yang dipelajari terasa jauh dari kehidupan mereka sehari-hari. Siswa hanya mengenal objek-objek Statistik dan Peluang dari apa yang digambar oleh guru di depan papan tulis atau dalam buku paket matematika,dan hampir tidak pernah mendapat kesempatan untuk memanipulasi objek-objek tersebut.
Rumusan Masalah dalam penelitian ini adalah Apakah penerapan model pembelajaran Contextual Teaching And Learning (CTL) dapat meningkatkan prestasi belajar matematika siswa kelas XI IPA 7 semester 3 SMA Negeri 1 Denpasar ?Untuk mengatasi hal tersebut di atas solusi yang diterapkan guru sebagai peneliti adalah mengupayakan penerapan model pembelajaran CTL dalam peningkatan prestasi belajar matematika. Model pembelajaran Contextual Teaching and Learning merupakan salah satu dari banyak cara yang bisa dilakukan guru dalam upaya meningkatkan mutu pembelajaran.Upaya tersebut dilaksanakan sebagai inovasi pembelajaran agar proses pembelajaran lebih inovatif, interaktif, menantang dan menyenangkan bagi siswa. Secara teoritis, salah satu model pembelajaran yang mampu membuat kondisi seperti itu adalah CTL (Contextual Teaching and learning). Menurut Wina Sanjaya (2006; 255) Contextual Teaching and learning (CTL) adalah suatu strategi pembelajaran yang menekankan kepada proses keterlibatan siswa secara penuh untuk dapat menemukan materi yang dipelajari dan menghubungkannya dengan situsi kehidupan nyata sehingga mendorong siswa untuk dapat menerapkannya dalam kehidupan mereka sehari-hari.Tujuan pembelajaran ini adalah untuk mengetahui seberapa besar peningkatan prestasi belajar matematika yang terjadi setelah langkahlangkah model pembelajaran CTL (Contextual Teaching and Learning) dilaksanakan dalam proses belajar mengajar.Penelitian ini diharapkan akan bermanfaat sebagai acuan dalam memperkaya teori dalam rangka peningkatan kompetensi guru. Sedangkan secara praktis penelitian ini diharapkan 
bermanfaat: 1)Bagi siswa, dapat meningkatkan prestasi belajar matematika dengan memanfaatkan model pembelajaran CTL. 2) Bagi guru, menambah wawasan untuk meningkatkan profesionalisme guru dengan mengadakan berbagai kegiatan ilmiah berupa penelitian dan penulisan karya ilmiah. 3) Bagi sekolah, khususnya SMA Negeri 1 Denpasar sebagai informasi yang berharga bagi teman-teman guru, kepala sekolah dalam rangka bersama-sama memperbaiki kualitas pembelajaran dan mutu pendidikan.

Pembelajaran kontekstual didasarkan pada hasil penelitian John Dewey (1916) yang menyimpulkan bahwa siswa akan belajar dengan baik jika apa yang dipelajari terkait dengan apa yang telah diketahui dan dengan kegiatan atau peristiwa yang terjadi disekelilingnya. Ada tiga hal yang harus dipahami. Pertama CTL menekankan kepada proses keterlibatan siswa untuk menemukan materi, kedua CTL mendorong agar siswa dapat menemukan hubungan antara materi yang dipelajari dengan situasi kehidupan nyata, ketiga mendorong siswa untuk dapat menerapkan dalam kehidupan sehari-hari. Contextual Teaching And Learning terdiri dari 7 komponen yaitu: 1) konstruktivisme (membangun), 2) bertanya (questioning), 3) inkuiry (menemukan), 4) masyarakat belajar (learning community), 5) pemodelan (modeling), 6) refleksi (reflection), dan 7) penilaian autentik (autentic assessment). Masnur Muslich dalam Constructivist Teaching (2007; 52) mencatat lima elemen yang harus diperhatikan dalam praktik pembelajaran kontekstual adalah sebagai berikut: 1) Pengaktifan pengetahuan yang sudah ada (activating knowledge). 2) Pemerolehan pengetahuan baru (acquiring knowledge) dengan cara mempelajari secara keseluruhan dulu, kemudian memperhatikan detailnya. 3) Pemahaman pengetahuan (understanding knowledge), yaitu dengan cara menyusun (a) konsep sementara (hipotesis), (b) melakukan sharing kepada orang lain agar mendapat tanggapan (validasi), dan atas dasar tanggapan itu (c) konsep tersebut direvisi dan dikembangkan. 4) Mempraktikkan pengetahuan dan pengalaman tersebut (Applying knowledge). 5) Melakukan refleksi (reflecting knowledge) terhadap strategi pengembangan pengetahuan tersebut. Prestasi belajar berasal dari kata "prestasi" dan "belajar". Prestasi berarti hasil yang telah dicapai sedangkan belajar adalah berusaha memperoleh kepandaian/ilmu (Depdiknas, 2011: 4). Dalam teori belajar matematika menurut J. Bruner dalam Hidayat (2004: 8) belajar merupakan suatu proses aktif yang memungtkinkan manusia untuk menemukan hal-hal baru di luar informasi yang diberikan kepada dirinya.Selanjutnya Hamalik (2005:68) menyatakan bahwa prestasi belajar merupakan sesuatu yang dibutuhkan seseorang untuk mengetahui kemampuan setelah melakukan kegiatan yang bersifat belajar, karena prestasi adalah hasil belajar yang mengandung unsur penilaian, hasil usaha kerja dan ukuran kecakapan yang dicapai suatu saat.

Menurut W.S. Winkel (2005) prestasi belajar adalah keberhasilan usaha yang dicapai seseorang setelah memperoleh pengalaman belajar atau mempelajari sesuatu. Selanjutnya menurut Muhamad Surya (2004:57) mengemukakan prestasi belajar adalah seluruh kecakapan hasil yang dicapai (achievement) yang diperoleh melalui proses belajar berdasarkan test belajar.Dari uraian di atas, tampak bahwa 
pengertian prestasi belajar yang diungkapkan tidak mengandung kontradiksi namun saling melengkapi. Dengan demikian dapat disimpulkan bahwa prestasi belajar merupakan kemampuan aktual yang dimiliki seorang siswa sebagai hasil usaha belajarnya. Kemampuan aktual tersebut dapat berupa pengetahuan, keterampilan, bakat, sikap, dan nilai yang dapat diukur tinggi rendahnya dengan jalan memberikan tugas-tugas kepada siswa yang relevan dengan sasaran yang diinginkan. Hasil yang diperoleh siswa dalam suatu mata pelajaran dinyatakan dalam bentuk nilai yang disebut prestasi belajar.

\section{METODE PENELITIAN}

Penelitian ini dilakukan di SMA Negeri 1 Denpasar. Rancangan penelitian ini adalah rancangan penelitian tindakan kelas yang disampaikan oleh Depdiknas sebagai berikut: Permasalahan, permasalahan tindakan I, Pelaksanaan tindakan I, Pengamatan/pengumpulan data I, Refleksi I, permasalahn baru, hasil refleksi, Perencanaan tindakan II, Pelaksanaan tindakan II, Pengamatan/pengumpulan data II, Refleksi II. Bila permasalahan belum terselesaikan, Dilanjutkankesiklus berikutnya. Adapun subjek penelitian ini adalah siswa kelas XI IPA 7 semester 3yang jumlahnya 34 orang, laki-laki 11 orang dan perempuan 23 orang. Objek penelitiannya adalah peningkatan prestasi belajar. Penelitian ini direncanakan akan berlangsung selama 6 bulan mulai bulan Juli sampai bulan Nopember tahun pelajaran 2016/2017. Metode yang digunakan untuk mengumpulkan data adalah tes, dan hasil penelitian ini adalah tes prestasi belajar. Sedangkan metode analisis datanya menggunakan analisis deskriptif.
Instrumen yang digunakan untuk menilai prestasi belajar siswa kelas XI IPA 7 adalah tes yang ada di masing-masing RPP. Indikator keberhasilan penelitian ini adalah pada siklus I prestasi belajar siswa mencapai nilai rata-rata 80 dengan ketuntasan belajar sebesar $80 \%$ dan pada siklus II mencapai nilai rata-rata 80 atau lebih dengan ketuntasan belajar minimal $85 \%$.

\section{HASIL PENELITIAN DAN PEMBAHASAN \\ Hasil Penelitian}

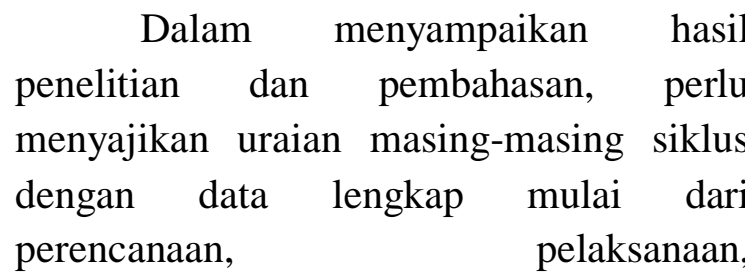
pengamatan/observasi dan refleksi yang berisi penjelasan tentang aspek keberhasilan dan kelemahan yang terjadi. Perlu ditambahkan hal yang mendasar, yaitu hasil perencanaan (kemajuan) pada diri siswa, lingkungan, guru, motivasi dan aktivitas belajar. Pada bagian ini disampaikan hasil observasi awal: dari 34 orang yang diteliti di kelas XI IPA 7 pada semester 3 tahun pelajaran 2016/2017 mencapai rata-rata 78,38 dan 21 orang lebih besar atau sama dengan KKM $(\geq 80)$ tuntas dan 13 orang belum tuntas $(<80)$ dan persentase ketuntasan belajar adalah 61,76 \%. Data tersebut menunjukkan rendahnya prestasi belajar Matematika di sekolah ini atau ketuntasan hasil belajar dibawah $80 \%$, sehingga harus mengupayakan cara lain untuk membenahi proses pembelajaran menjadi lebih baik.

\section{Siklus I}

\subsubsection{Rencana Tindakan I}

Hasil yang didapat dari kegiatan perencanaan meliputi: a) Menyusun jadwal 
pelaksanaan. b) Menyusun rencana pelaksanaan pembelajaran (RPP). c) Berkonsultasi dengan temen-temen guru. d) Merencanakan model pembelajaran yang paling tepat untuk menyelesaikan masalah yang ada. e) Menyusun format penilaian. $\mathrm{f}$ ) Mempersiapkan alat-alat yang akan digunakan membantu proses pembelajaran

3.1.2 Pelaksanaan tindakan I

Pelaksanaan tindakan I meliputi: a)Membawa semua persiapan ke kelas. b)Memulai pelaksanaan pembelajaran dengan pembelajaran pendahuluan yaitu: mengucapkan salam, memeriksa kebersihan kelas, melakukan absensi, memotivasi siswa agar giat belajar, melakukan apersepsi, menyampaikan tujuan pembelajaran serta cakupan materi yang sedang diajarkan. c)Melakukan pembelajaran inti explorasi. d)Melakukan pembelajaran inti elaborasi. e)Melakukan pembelajaran inti konfirmasi. f)Melakukan kegiatan pembelajaran penutup. g) Melakukan penilaian proses.h)Mengakhiri pembelajaran dengan mengucapkan salam penutup.

\subsubsection{Observasi/Pengamatan Siklus I}

Pengamatan dilakukan setelah proses pembelajaran dilaksanakan dalam 3 kali pertemuan dengan memberikan tes prestasi belajar. Dalam pengamatan ini peneliti mengawasi siswa dengan ketat agar tidak ada siswa yang bekerjasama dalam mengerjakan soal.Hasil pengamatan pada siklus I adalah : dari 34 siswa jumlah nilai 2692, dengan rata-rata 79,18 dan 25 orang diatas KKM, 9 orang belum tuntas (di bawah KKM), ketuntasan belajar 73,53 \% jadi masih dibawah idikator keberhasilan yaitu $80 \%$.

\subsubsection{Refleksi Siklus I}

Refleksi merupakan kajian secara menyeluruh tindakan yang telah dilakukan berdasarkan data yang telah terkumpul, kemudian dilakukan evaluasi guna menyempurnakan tindakan. Refleksi menyangkut analisis, sintesis, dan penilaian terhadap hasil pengamatan atas tindakan yang dilakukan (Hopkin, 1993 dalam Suharsimi Arikunto, Suhardjono, Supardi, 2006: 80).

3.1.4.1 Analisis kuantitatif Prestasi belajar siswa siklus I

a. Rata-rata (mean) dihitung dengan:

$\bar{X}=\frac{\text { Jumla } h \text { nilai }}{\text { Jumla } h \text { siswa }}=\frac{2692}{34}=79,18$

b. Median (titik tengahnya) adalah 80

c. Modus (angka yang paling banyak/paling sering muncul) setelah diasccending/diurut angka tersebut adalah: 80

d. Untuk persiapan penyajian dalam bentuk grafik maka hal-hal berikut dihitung terlebih dahulu.Banyak kelas $(\mathrm{K})=6$. Rentang kelas $(\mathrm{r})=$ skor maksimum skor minimum $=86-66=20$. Panjang kelas interval (i) $=\frac{r}{K}=\frac{20}{6}=3,33 \rightarrow 4$. Data di atas dapat disajikan dalam bentuk grafik/histogram sebagai berikut:

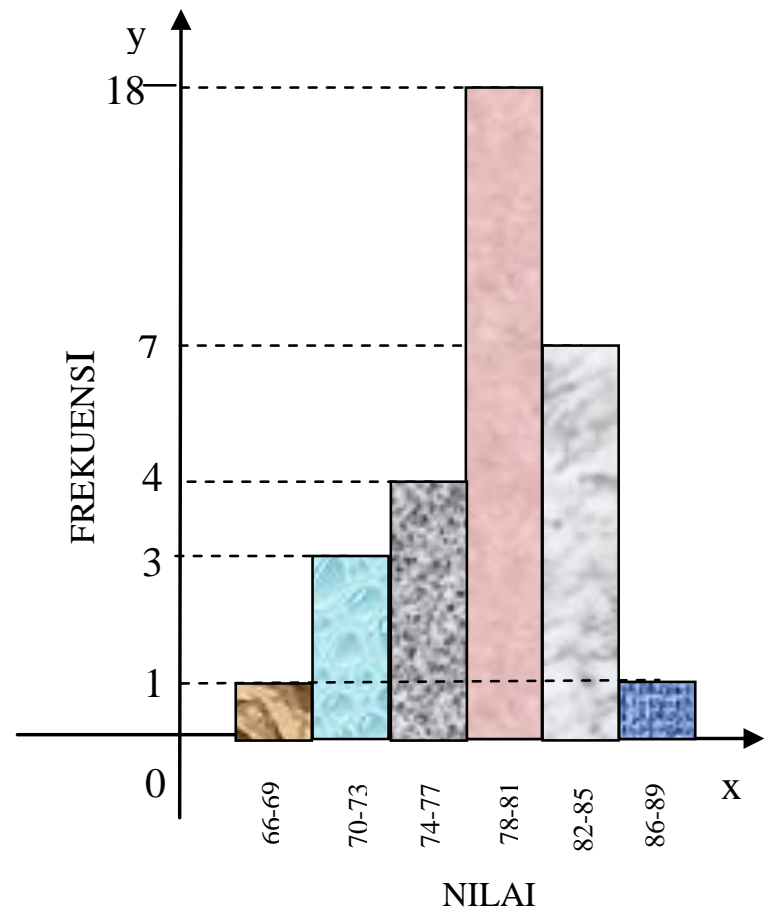

Memperhatikan pendapat para ahli pendidikan yang telah disampaikan di awal 
penulisan refleksi, bahwa dalam refleksi dilakukan analisis, sintesis dan penilaian/evaluasi sehingga sintesis merupakan campuran berbagai pengertian sehingga merupakan kesatuan yang selaras. 1. Sintesis

Sintesis yang dapat disampaikan adalah ada 25 orang dari 34 siswa yang ditulis memperoleh nilai diatas KKM namun masih ada 9 orang ( $26,47 \%$ ) siswa yang tergolong belum mampu memenuhi pencapaian keberhasilan pada siklus ini. Dari data yang diperoleh dapat diberikan sintesis bahwa usulan keberhasilan pada siklus I belum terpenuhi.

2. Penilaian siklus I

Sesuai fakta yang berhasil ditemui di lapangan, pada siklus I ini ditemukan beberapa kekurangan-kekurangan dan kelebihan-kelebihan yang mesti dijabarkan. Kekurangan-kekurangan/kelemahankelemahan yang ada dari pelaksanaan tindakan siklus I adalah:

1).Guru belum sepenuhnya menguasai keterampilan-keterampilan mengajar. 2).Peserta didik belum sepenuhnya berniat untuk meningkatkan kemampuan belajar mereka. 3). Banyak siswa yang masih lainlain, mereka belum terbiasa memusatkan perhatiannya dalam belajar.

Sedangkan kelebihan yang ditemukan pada pelaksanaan tindakan siklus I adalah: 1).Semua persiapan sudah dibuat secara maksimal sehingga peneliti paham betul terhadap cara pembelajaran yang baru. 2).Pembelajaran lebih produktif dan mampu menumbuhkan penguatan konsep kepada siswa karena metode pembelajaran CTL menganut aliran konstruktivisme, dimana seorang siswa dituntun untuk menemukan pengetahuannya sendiri. 3). Kebiasaan peserta didik aktif bekerja mampu ditingkatkan dengan cara ini.

\section{Siklus II}

\section{Rencana Tindakan II}

Hasil yang didapat dari kegiatan perencanaan meliputi: a) Menyusun RPP mengikuti model pembelajaran Contextual Teaching and Learning (CTL). b) Menyiapkan bahan-bahan pendukung pembelajaran seperti buku paket, buku Lembar Kerja Siswa (LKS). c) Membaca teori-teori tentang model pembelajaran Contextual Teaching and Learning (CTL), untuk dapat dilaksanakan dengan benar di lapangan. d) Membuat soal-soal penilaian yang berhubungan dengan kompetensi dasar. e) Mempersiapkan alat-alat yang akan digunakan membantu proses pembelajaran, f) Membaca dengan baik pedoman-pedoman yang diberikan oleh Departemen pendidikan dalam menyusun perencanaan agar mampu nanti melakukan pembelajaran sesuai harapan, g) Menyusun materi pembelajaran

\section{Pelaksanaan Tindakan II}

Dalam pelaksanaan tindakan pada siklus II meliputi:a)Membawa semua persiapan ke kelas. b) Memulai pelaksanaan pembelajaran dengan pembelajaran pendahuluan yaitu: mengucapkan salam, melakukan absensi, memotivasi siswa agar giat belajar, melakukan apersepsi, menyampaikan tujuan pembelajaran serta cakupan materi yang sedang diajarkan. c) Melakukan pembelajaran inti explorasi. d) Melakukan pembelajaran inti elaborasi. e) Melakukan pembelajaran inti konfirmasi. f) Melakukan kegiatan pembelajaran penutup. g) Mengakhiri pembelajaran dengan mengucapkan salam penutup. h) Melakukan penilaian proses

\section{Observasi/Pengamatan II}

Pengamatan dilakukan setelah proses pembelajaran dilaksanakan dalam 3 kali 
pertemuan dengan memberikan tes prestasi belajar. Dalam pengamatan ini peneliti mengawasi siswa dengan ketat agar tidak ada siswa yang bekerjasama dalam mengerjakan soal. Hasil pengamatan pada siklus II adalah : dari 38 siswa jumlah nilai 2856, dengan rata-rata 84,0 dan 33 orang diatas KKM, 1 orang belum tuntas (dibawah KKM), ketuntasan belajar $97,06 \%$ jadi sudah meningkat dari idikator yang ditentukan yaitu $85 \%$.

\section{Refleksi Siklus II}

Observasi/Pengamatan II

Analisis kuantitatif Prestasi belajar siswa siklus II

1. Rata-rata (mean) dihitung dengan:

$\bar{X}=\frac{\text { Jumla } h \text { nilai }}{\text { Jumla } h \text { siswa }}=\frac{2856}{34}=84,0$

2. Median (titik tengahnya) adalah: 84 .

3. Modus (angka yang paling banyak/paling sering muncul) setelah diasccending/diurut angka tersebut adalah: 85

4. Untuk persiapan penyajian dalam bentuk grafik maka hal-hal berikut dihitung terlebih dahulu.1). Banyak kelas (K) = 6 . Rentang kelas $(\mathrm{r})=$ kor maksimum - skor minimum $=91-75=16$.

5. Panjangkelasinterval(i) $=\quad \frac{r}{K}=\frac{16}{6}=$ $2,67 \sim 3$.

6. Data di atas dapat disajikan dalam bentuk grafik/histogram sebagai berikut:

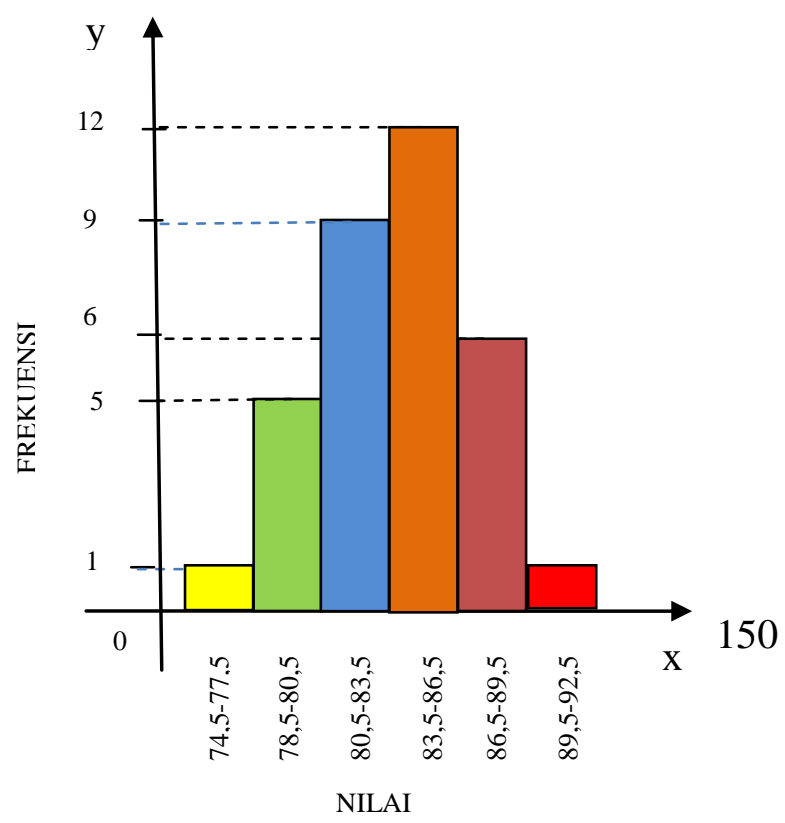

Kekurangan-kekurangan/kelemahan-

kelemahan yang ada dari pelaksanaan tindakan siklus II adalah:

1. Kemampuan siswa yang berbeda-beda tidak mampu untuk memasukkan ilmu secara cepat sehingga dalam pelaksanaannya memakan waktu yang agak lama.

2. Penggunaan metode baru dalam pelaksanaannya masih sama dengan metode yang sering digunakan.

3. Keterampilan bertanya yang sudah dimilki guru dengan Tanya jawab multi arah ternyata memakan waktu yang cukup banyak.

Sedangkan kelebihan yang ditemukan pada pelaksanaan tindakan siklus II adalah:

1. Suatu kebanggaan terjadi pada diri guru akibat prestasi belajar siswa mampu ditingkatkan.

2. Kelebihan yang lain adalah model ini mampu menunjukkan kelebihan-kelebihan dan peningkatan prestasi sesuai harapan guru sebagai peneliti.

3. Model ini mampu meningkatkan prestasi siswa yang lebih baik terhadap proses yang dilakukan guru dan mampu membuat siswa lebih terkesan dalam mengikuti proses belajar mengajar.

\section{PEMBAHASAN}

Upaya yang telah dilakukan secara maksimal dalam pemecahan masalah yang ada, memudahkan anak dalam melakukan tindakan, perubahan prilaku yang dilakukan lewat pembiasaan-pembiasaan agar terbiasa belajar dan tidak hanya bermain telah dilakukan secara maksimal.

Data awal menunjukkan hanya 34 orang siswa kelas XI IPA 7 yang mencapai ketuntasan belajar menunjukkan rendahnya peningkatan mutu pendidikan di sekolah ini. Kelemahan yang terjadi adalah akibat dominasi guru dalam pembelajaran yang sulit untuk dikurangi, disamping itu teoriteori ahli yang mesti digunakan belum dibaca. Sehingga pembelajaran yang 
dilakukan guru justru monotun dari hari ke hari dan guru mengajar dengan cara yang itu-itu saja tanpa perubahan. Hal tersebut justru menjerumuskan peserta didik pada tingkat penguasaan materi yang amat rendah. Setelah semua hal tersebut mampu diperbaiki maka pada siklus I terlihat kemajuan yang diperoleh yaitu nilai ratarata kelas sudah meningkat menjadi 79,18 dengan ketuntasan belajar mencapai $73,53 \%$. Walaupun sudah terjadi peningkatan, namun hasil tersebut belum mampu mencapai kriteria indikator keberhasilan penelitian yang sudah dicanangkan yaitu nilai siswa mencapai 80 untuk rata-rata kelas dengan ketuntasan belajar minimal $80 \%$. Oleh karena itu perbaikan masih terus diupayakan. Kelemahan dalam hal guru selalu mendominasi pembelajaran sudah dikurangi dengan guru lebih sedikit berbicara dan lebih giat memberi tugas untuk dikerjakan. Guru juga giat membantu peserta didik pada saat mereka giat bekerja dan giat memberi arahan-arahan pada saat mereka berdiskusi agar mereka giat bekerja dan tidak hanya mengganggu. Demikian kelebihan-kelebihan yang telah dilaksanakan. Bagi mereka yang masih santai dan menunggu perintah guru diarahkan dan diberi penekanan-penekanan agar jangan selalu menunggu perintah dari guru untuk melakukan sesuatu. Mereka yang belum aktif bertanya diarahkan agar aktif bertanya dan dituntun dengan menyuruh mereka menulis sebuah pertanyaan untuk ditanyakan sehingga keaktifan berbicara dan berargumentasi yang hamper mati pada saat pembelajaran awal mampu dioptimalkan. Para siswa yang merasa masih rendah kemampuannya dan merasa bahwa mata pelajaran peluang adalah mata pelajaran sulit, menakutkan dan membosankan kemudian diberikan soal-soal yang mudah bagi mereka untuk dijawab sehingga timbul rasa bangga dan percaya diri mereka sehingga momok yang masih tersimpan dalam dirinya bahwa mata pelajaran matematika adalah mata pelajaran yang sulit dapat dihindari dan diatasi.

Hasil yang didapat pada silus II menunjukkan bahwa proses yang dilaksanakan sudah mampu meningkatkan perkembangan peserta didik, perubahan yang terjadi sudah cukup signifikan sehingga tidak perlu dilanjutkan ke siklus berikutnya.

Dari hasil yang didapat pada siklus II menunjukkan 97,06\% anak sudah berhasil sedangkan tuntutan keberhasilan penelitian adalah $80 \%$, hasil ini telah menjawab tujuan penelitian sehingga penelitian ini diakhiri. Akhirnya model pembelajaran Contextual Teaching and Learning (CTL) mampu meningkatkan prestasi belajar anak/siswa.

\section{Simpulan}

Berdasarkan hasil penelitian di atas dapat disampaikan simpulan bahwa model pembelajaran Contextual Teaching and Learning (CTL) yang telah dilaksanakan dan mampu menjawab rumusan masalah penelitian ini serta mampu membuktikan bahwa tujuan penelitian ini sudah dapat dicapai. Sebagai bukti atas pencapaian tersebut nilai rata-rata awal 78,38naik menjadi 79,18 pada siklus I dan pada siklus II naik menjadi 84,00. Dari data awal siswa yang tuntas hanya 21 siswa sedangkan pada siklus I menjadi lebih banyak yaitu 25 siswa dan pada siklus II menjadi cukup banyak yaitu 33 siswa. Perlu adanya penelitian yang lebih lanjut, karena hasil penelitian ini hanya dilakukan di SMA Negeri 1 Denpasar tahun pelajaran 2016/2017. 
Saran

Dari hasil penelitian yang diperoleh dari uraian sebelumnya agar proses belajar mengajar di SMA Negeri 1 Denpasar lebih efektif dan lebih memberikan hasil yang oftimal bagi siswa, maka disampaikan saran sebagai berikut: 1) Dalam melaksanakan proses pembelajaran pada mata pelajaran matematika disarankan agar guru-guru membuat persiapan yang matang dan mampu menentukan atau memilih topik yang benar-benar bisa diterapkan dengan model pembelajaran Contextual Teaching and Learning (CTL) agar diperoleh hasil yang optimal. 2) Disarankan bagi guru yang ingin meningkatkan prestasi belajar siswa, hendaknya lebih sering melatih siswa dengan kegiatan penemuan, walau dalam taraf yang sederhana, dimana siswa nantinya dapat menemukan pengetahuan baru, memperoleh konsep dan keterampilan, sehingga siswa berhasil atau mampu memecahkan masalah-masalah yang dihadapinya. 3) Perlu adanya penelitian yang lebih lanjut, karena hasil penelitian ini hanya dilakukan di SMA Negeri 1 Denpasar tahun pelajaran 2016/2017.

\section{DAFTAR PUSTAKA}

Arikunto, S.; Suhardjono; Supardi. (2006). Penelitian tindakan kelas. Jakarta: PT Bumi Aksara.

Djamarah, S. B. (2002). Prestasi belajar dan kompetensi guru. Surabaya: Usaha Nasional.

Depdiknas. (2011). Membimbing guru dalam penelitian tindakan kelas. Jakarta: Pusat Pengembangan Tenaga Kependidikan Badan Pengembangan Sumber Daya Manusia Pendidikan dan Menjaminan Mutu Pendidikan.

Hamalik, O. (2002). Psikologi belajar dan mengajar. Bandung: Sinar Baru.
Hidayat. (2004). Diklat kuliah teori pembelajaran matematika. Semarang:

Iskandar. (2011). Penelitian tindakan kelas. Jakarta: Gaung Persada (GP) Press.

Kunandar.(2009). Langkah mudah penelitian tindakan kelas sebagai pengembangan profesi guru. Jakarta: Rajawali Pers.

Masnur M, (2007). Pembelajaran berbasis kompetensi dan kontekstual. Bumi Aksara.

Purwanto, N,(2000). Psikologi pendidikan. Bandung; Rosdakarya

.Slameto. (2000). Belajar dan faktor-faktor yang mempengaruhinya. Jakarta: Rineka Cipta.

Surya, M. (2004). Psikologi pembelajaran dan pengajaran. Bandung: Pustaka Bani Quraisy.

Wina S, (2006). Strategi pembelajaran berorientasi standar proses pendidikan.Kencana Prenada Media,

Winkel, W.S.(2005). Psikologi pengajaran. Cetakan Ketujuh. Yogyakarta; Media Abadi. 